\title{
Distribution and feeding ecology of the angelfishes (Pomacanthidae) in Shalateen region, Red Sea, Egypt
}

\author{
Magdy A. Alwany \\ Department of Marine Sci., Faculty of Sci., Suez Canal Univ., Ismailia, Egypt \\ (e-mailmagdy.elalwany@yahoo.com)
}

\begin{abstract}
This study aimed to estimate the distribution and feeding ecology of the angelfishes (Family Pomacanthidae) in Shalateen region, Red Sea, Egypt. The total number of recovered species was six species, where Centropyge multispinis and Pygoplites diacanthus were the most abundant at most sites, while Pomacanthus imperator and P. maculosus were the lowest. The royal angelfish, Pygoplites diacanthus, was represented in all sites and all reef zones in Shalateen region. Most angelfish species were not found on the reef flat (except Pygoplites diacanthus), since they prefer the reef slope and increase with depth. Based on the number of individuals, the reef flat comprised only $2.7 \%$ of the total Pomacanthids population, while the slope comprised $97.3 \%$ of population (34.1\% at $1-10 \mathrm{~m}$ depth and $63.2 \%$ at $10-20 \mathrm{~m}$ depth). The highest feeding rate was recorded for $C$. multispinis, with $84.3 \pm 26.4$ bites. $(5 \mathrm{~min})^{-1}$, while the lowest was recorded for $P$. maculosus, with $58.9 \pm 21.6$ bites. $(5 \mathrm{~min})^{-1}$. Most species of angelfishes use biting mode for feeding and diurnal feeders, except Genicanthus caudovittatus that use ram mode for feeding on zooplankton and nocturnal feeder. Feeding guilds are divided into three categories: a) invertebrate-feeders, represented by three species, namely P. asfur, P. imperator and $P$. maculosus, b) omnivores, represented by two species, C. multispinis and Pygoplites diacanthus, c) zooplankton feeder, represented by only $G$. caudovittatus.
\end{abstract}

Key words: distribution, abundance, diversity, angelfishes, Red Sea, Egypt

\section{INTRODUCTION}

The Red Sea is not just a unique environment, but also of high diversity with great scientific and ecological importance. There are many changes in the Red Sea communities along $18^{\circ}$ of latitude. Such specific habitat connecting the distribution of reef fishes to a certain type of specific utilization of the coral reef. Coral reef fish communities are heterogeneous at many scales and one of the most complex marine ecosystems in which fish communities reach their highest degree of diversity (Harmelin-Vivien, 1989). Many biotic and abiotic factors are controlling the distribution and abundance of reef fishes. In the same time, fish assemblages are helpful in illuminating many important ecological processes, which help to study the contexts of the environments. Angelfishes 
(Pomacanthidae) are among the most spectacularly coloured and widely recognized groups of coral reef-associated fishes.

The angelfishes were once grouped with the butterflyfishes in the same family. They share a number of characteristics, such as deep compressed bodies, ctenoid scales, a single un-notched dorsal fin and a small mouth with brush-like teeth. Pomacanthidae has relatively low species $(88$ species, belonging to 8 genera), yet it represents one of the most conspicuous components in extant coral reef fish assemblages, with representatives in all tropical seas (Allen et al., 1998; Delbelius et al., 2003). The genus Centropyge has the richest species, where it includes 32 species (Pyle, 2003). Within the family, there is a diverse range of ecological traits, including striking variation in body size, colour patterns, reproductive systems and diets, which range from planktivory to omnivory (Alwany, 1997; Bellwood et al., 2004). Most of angelfishes are diurnal, the species of Pomacanthus and Pygoplites feed mainly on sponges as adults, where Genicanthus species feed on zooplankton and those of Centropyge are grazers on algae and detritus (Khalaf and Kochzius, 2002a and b). Angelfishes generally occur as solitary individuals or in pairs. As pelagic spawners, marine angelfishes release many tiny buoyant eggs into water, which then become part of the plankton. The eggs float freely with currents until hatching, a high number falling victim to planktonic feeders (Thresher, 1982).

Despite its prominent status among the coral reef fishes, the biology and ecology of the Pomacanthidae has not been yet studied in details, especially in the Red Sea. This study was performed to establish a data base on this subject which is urgently needed. This study aimed also to describe the distribution of angelfishes in Shalateen region. In addition, it aimed to be the first detailed investigation on distribution of angelfishes in this region from the Red Sea. Moreover, this study provides important data on the feeding rate, mode, guild, time and prey items of the family Pomacanthidae on fringing reefs in the northern Red Sea.

\section{MATERIALS AND METHODS}

The field observations were carried out by snorkeling on reef flat and reef edge, and by SCUBA diving to about $20 \mathrm{~m}$ depth. Underwater observations were recorded by using water proof papers, pencils and water resistant watch. Species identification was based on Randall (1983).

\section{Study area}

The research was conducted at six different reefs in Shalateen region, Red Sea, Egypt (Figure 1). The study area is located on a shallow reef flat and reef slope down to depths of about $20 \mathrm{~m}$. Site1 is located south Ras Banas (Mirear: $\left.23^{\circ} 11^{\prime} \mathrm{N}, 35^{\circ} 38^{\prime} \mathrm{E}\right)$ and it is a barrier reef. The reef flat $(30-40 \mathrm{~m}$ wide) and slope (relatively steep) comprise well-developed coral communities. Site 2 (Shalateen Coast: $23^{\circ} 09^{\prime} \mathrm{N}, 35^{\circ} 36^{\prime} \mathrm{E}$ ) is located at the coast of Shalateen City. The reef flat (50-70 m wide) is rich in algae and echinoderms, while reef 
slope (gentle) is rich in corals and algae. Site 3 (Marsa Shab: $22^{\circ} 30^{\prime} \mathrm{N}, 36^{\circ} 11^{\prime}$ E) is coastal reef and has turbid water. The reef flat (40-70 m wide) is rich in corals and algae and reef slope (relatively steep) having well-developed corals and algal communities. Site 4 (Sial Island: $22^{\circ} 47^{\prime} \mathrm{N}, 36^{\circ} 12^{\prime} \mathrm{E}$ ) is small island has fringing reef. The reef flat (20-30 $\mathrm{m}$ wide) is rich in coral and algae. Its reef slope (gently sloping) is characterized by diverse coral communities. Site 5 (Dibia Patch: $22^{\circ} 23^{\prime} \mathrm{N}, 36^{\circ} 29^{\prime} \mathrm{E}$ ) holds large patched reefs. The reef flat (20$30 \mathrm{~m}$ wide) is rich in algae, while the reef slope (gently sloping) is rich in corals and algal communities. Site 6 (Abu Ramad: $22^{\circ} 23^{\prime} \mathrm{N}, 36^{\circ} 25^{\prime} \mathrm{E}$ ) is located at the coast of Abu Ramad City. The reef flat (50-70 m wide) is rich in coral and algae. Its reef slope (relatively steep) is characterized by well-developed coral communities.

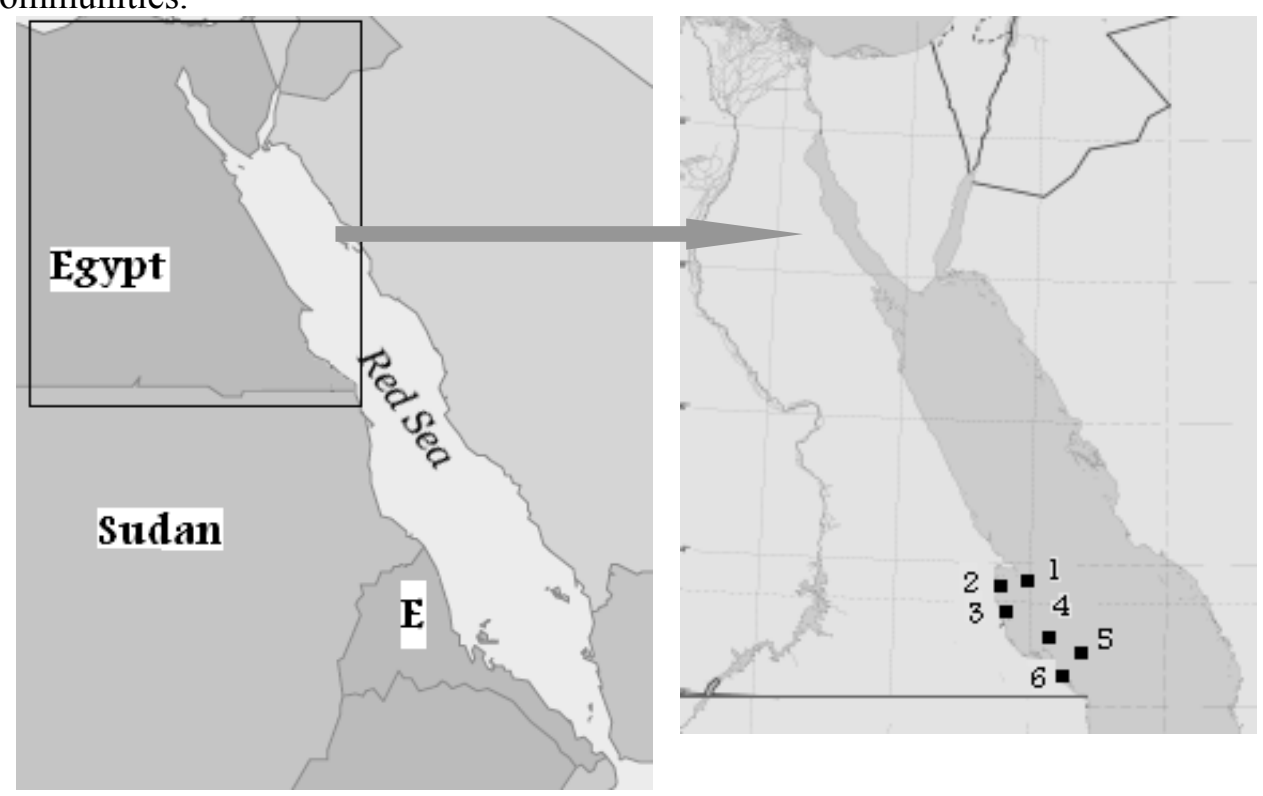

Figure 1: Map of Red Sea showing the positions of different sites in the study area of Egyptian coast.

\section{Visual census}

Underwater visual census techniques have been used to record fish densities and abundances on reefs since more than fifty years ago (e.g. Brock, 1954) and form the basis for population ecology studies and management decisions (Harmelin-Vivien et al., 1985). Furthermore, they provide rapid estimates of the relative abundance and distribution of reef fishes (Samoilys and Carlos, 2000). Here, members of the angelfishes were counted using this approach along transects $\left(100 \mathrm{~m} \mathrm{X} 6 \mathrm{~m} \mathrm{X} 1 \mathrm{~m}=600 \mathrm{~m}^{3}\right)$ on the reef flat (RF, 
depth: 0.5-1 m) and reef slope (RS, depth: 1-10 \& 10-20 m). Transect width was estimated visually, and time used to estimate the length of transect, was as long as to avoid the disturbance to fishes that occur when a line is laid. Fishes were observed using snorkeling and SCUBA diving during day-time from 1100 to $1400 \mathrm{~h}$.

\section{Feeding activities}

The feeding rates of 98 angelfishes were measured as the biting action of fish per unit time (feeding rate $=$ number of bites per minute). Randomly selected, mature fishes of the same size and condition were observed by snorkeling and SCUBA diving at a distance of 1-3 m. The observer swam slowly to minimize disturbance. Bites per food item were counted for six consecutive periods of 5 minutes for each individual (after Reese, 1975, 1977). The trophic categories or guilds based on visual field observations were recorded; (IV: invertebrate-feeder; OM: omnivore; PL: planktivore). Also, the feeding mode of angelfish species were recorded; (B: biting; R: ram). Also, the time of feeding was recorded (diurnal or nocturnal).

\section{Data analysis}

The data were analysed statistically using the software packages PRIMER (V 5.0) and SPSS (V 15). Species richness was expressed by considering the number of species (D), and species diversity and homogeneity were determined using the Shannon-Wiener diversity index $\left(\mathrm{H}^{\prime}\right)$ and the evenness index $\left(\mathrm{J}^{\prime}\right)$ (Pielou, 1966). One-way ANOVA was carried out with SPSS program. When necessary, the data were square root transformed to produce normality and homogeneity of variance.

\section{General distribution and abundance}

RESULTS

The list and number of surgeonfish species at reef flat and reef slope (1$10 \& 10-20 \mathrm{~m}$ ) in Shalateen region are shown in Table (1). In general, there were six species (Centropyge multispinis, Genicanthus caudovittatus, Pomacanthus asfur, P. imperator, P. maculosus and Pygoplites diacanthus). C. multispinis and Pygoplites diacanthus were the most abundant at most sites $\left(2.4 \pm 0.6 \mathrm{fish} / 600 \mathrm{~m}^{3}\right.$ and $2.0 \pm 0.4 \mathrm{fish} / 600 \mathrm{~m}^{3}$, respectively). In contrast, $P$. imperator and $P$. maculosus were the lowest at most sites $\left(0.2 \pm 0.3 \mathrm{fish} / 600 \mathrm{~m}^{3}\right.$ and $0.9 \pm 0.7$ fish $/ 600 \mathrm{~m}^{3}$, respectively). The royal angelfish, Pygoplites diacanthus, was represented in all sites and all reef zones in Shalateen region (Figrs. 3 and 4). Sites 1 and 6 (Mirear and Abu Ramad, respectively) have the highest number of species (6 species), while site 5 (Dibia Patch) has the lowest number of species (3 species). One-way ANOVA showed that the influence of species is significant $(p=0.045$, Table 2$)$, the influence of zones highly significant $(p<0.001)$, but the influence of sites was not significant $(p=0.976)$. 
Table (1). The mean abundance (mean \pm SD) of species of the angelfishes on the reef flat and reef slope $(1-10 \& 10-20 \mathrm{~m})$, and diversity indices at different sites in Shalatenn region in the northern Red Sea.

\begin{tabular}{|l|cccccc|}
\hline \multicolumn{1}{|c|}{ Species } & site 1 & site 2 & site 3 & site 4 & site 5 & site 6 \\
\hline Reef flat (0.5-1.0 m) & & & & & & \\
Centropyge multispinis & 0 & 0 & 0 & 0 & 0 & 0 \\
Genicanthus caudovittatus & 0 & 0 & 0 & 0 & 0 & 0 \\
Pomacanthus asfur & 0 & 0 & 0 & 0 & 0 & 0 \\
Pomacanthus imperator & 0 & 0 & 0 & 0 & 0 & 0 \\
Pomacanthus maculosus & 0 & 0 & 0 & 0 & 0 & 0 \\
Pygoplites diacanthus & $0.7 \pm 0.6$ & $0.3 \pm 0.6$ & $0.3 \pm 0.6$ & $0.7 \pm 0.6$ & $1.3 \pm 0.6$ & $0.7 \pm 0.6$ \\
\hline \multicolumn{1}{|c}{ Reef slope (1-10 m) } & site 1 & site 2 & site 3 & site 4 & site 5 & site 6 \\
\hline Centropyge multispinis & $1.7 \pm 0.6$ & 0 & $1.0 \pm 1.0$ & $2.3 \pm 1.5$ & $2.7 \pm 1.2$ & $2.7 \pm 1.2$ \\
Genicanthus caudovittatus & 0 & 0 & 0 & 0 & 0 & 0 \\
Pomacanthus asfur & $3.3 \pm 1.2$ & $3.0 \pm 1.0$ & $4.0 \pm 1.0$ & $3.3 \pm 0.6$ & $6.0 \pm 2.0$ & $0.7 \pm 1.2$ \\
Pomacanthus imperator & 0 & 0 & 0 & 0 & 0 & $1.7 \pm 0.6$ \\
Pomacanthus maculosus & $3.3 \pm 0.3$ & $3.7 \pm 1.5$ & $3.7 \pm 0.6$ & $1.0 \pm 1.0$ & 0 & $0.7 \pm 1.2$ \\
Pygoplites diacanthus & $1.3 \pm 0.6$ & $1.3 \pm 0.3$ & $0.7 \pm 0.6$ & $1.0 \pm 1.0$ & $0.7 \pm 0.6$ & $0.7 \pm 0.6$ \\
\hline Species richness (D) & 1.326 & 0.962 & 1.339 & 1.479 & 0.893 & 2.137 \\
Evenness (J') & 0.946 & 0.928 & 0.839 & 0.907 & 0.763 & 0.892 \\
Shannon-Wiener (H') & 1.311 & 1.02 & 1.162 & 1.258 & 0.838 & 1.436 \\
\hline \multicolumn{1}{|c|}{ Reef slope (10-20 m) } & site 1 & site 2 & site 3 & site 4 & site 5 & site 6 \\
\hline Centropyge multispinis & $6.3 \pm 1.5$ & $5.0 \pm 1.7$ & $4.3 \pm 1.5$ & $7.3 \pm 0.6$ & $5.7 \pm 0.6$ & $5.0 \pm 1.7$ \\
Genicanthus caudovittatus & $8.7 \pm 2.5$ & $3.7 \pm 1.5$ & 0 & $6.7 \pm 2.1$ & 0 & $4.3 \pm 1.2$ \\
Pomacanthus asfur & $0.3 \pm 0.6$ & $0.7 \pm 0.6$ & $1.7 \pm 0.6$ & 0 & $0.7 \pm 0.6$ & $1.3 \pm 0.6$ \\
Pomacanthus imperator & $0.3 \pm 0.6$ & $0.3 \pm 0.6$ & 0 & $1.0 \pm 0$ & 0 & $0.7 \pm 0.6$ \\
Pomacanthus maculosus & $0.7 \pm 0.6$ & 0 & $1.7 \pm 1.2$ & $0.7 \pm 0.6$ & 0 & $0.3 \pm 0.6$ \\
Pygoplites diacanthus & $4.3 \pm 0.6$ & $3.7 \pm 1.2$ & $3.3 \pm 0.6$ & $4.3 \pm 1.5$ & $3.7 \pm 0.6$ & $6.3 \pm 1.2$ \\
\hline Species richness (D) & 1.653 & 1.541 & 1.251 & 1.335 & 0.865 & 1.733 \\
Evenness (J') & 0.721 & 0.819 & 0.942 & 0.828 & 0.797 & 0.810 \\
Shannon-Wiener (H') & 1.291 & 1.318 & 1.306 & 1.332 & 0.876 & 1.452 \\
\hline
\end{tabular}

Table (2). One-way ANOVA performed on abundance of angelfishes.

\begin{tabular}{llllll}
\hline Factor & Source of variation & $\mathrm{df}$ & MS & F value & P value \\
\hline \multirow{3}{*}{ Sites } & between groups & 5 & 0.681 & 0.161 & 0.976 \\
& $\begin{array}{l}\text { within groups } \\
\text { total }\end{array}$ & 102 & 4.225 & & \\
\hline \multirow{3}{*}{ zones } & $\begin{array}{l}\text { between groups } \\
\text { within groups }\end{array}$ & 2 & 60.120 & 20.093 & $<0.001^{* *}$ \\
& total & 105 & 2.992 & & \\
\hline \multirow{3}{*}{ Species } & between groups & 5 & 9.015 & 2.362 & $0.045^{*}$ \\
& $\begin{array}{l}\text { within groups } \\
\text { total }\end{array}$ & 102 & 3.817 & & \\
\hline & $*$ Significant at $\mathrm{p}<0.045$ & & & \\
& ** Highly significant at $\mathrm{p}<0.0001$ & & &
\end{tabular}

\section{Habitat distribution and diversity}

Some fish species were more widespread than others, which may be explained by associated preferences for certain habitats. Based on the number of species, the pattern of habitat preferences is clear in the distribution of 
Pomacanthidae in Shalateen region (Figrs. 2). All angelfish species were not found on the reef flat (except Pygoplites diacanthus), but they preferred the reef slope and increase with depths (Fig. 3). Based on the number of individuals, the reef flat comprised only $2.7 \%$ of the total Pomacanthids population, while the reef slope comprised $97.3 \%$ of population (34.1\% at 1-10 m depth and $63.2 \%$ at $10-20 \mathrm{~m}$ depth). On reef flat, only one species was recorded, so no diversity indices can be calculated. On reef slope (1-10 m), the average species richness ranged from 0.893 at site 5 (Dibia Patch) to 2.137 at site 6 (Abu Ramad). The highest evenness index $\left(\mathrm{J}^{\prime}\right)$ was recorded at site $1(0.946)$, while site 5 yielded the lowest value $(0.763)$. Average Shannon-Wiener diversity $\left(\mathrm{H}^{\prime}\right)$ varied between 0.838 at site 5 and 1.436 at site 6 (Table 1). On reef slope (10-20 m), the average species richness ranged from 0.865 at site 5 to 1.733 at site 6 . The highest evenness index $\left(\mathrm{J}^{\prime}\right)$ was recorded at site $3(0.942)$, while site 1 yielded the lowest value $(0.721)$. Average Shannon-Wiener diversity $\left(\mathrm{H}^{\prime}\right)$ varied between 0.876 at site 5 and 1.452 at site 6 (Table 1).
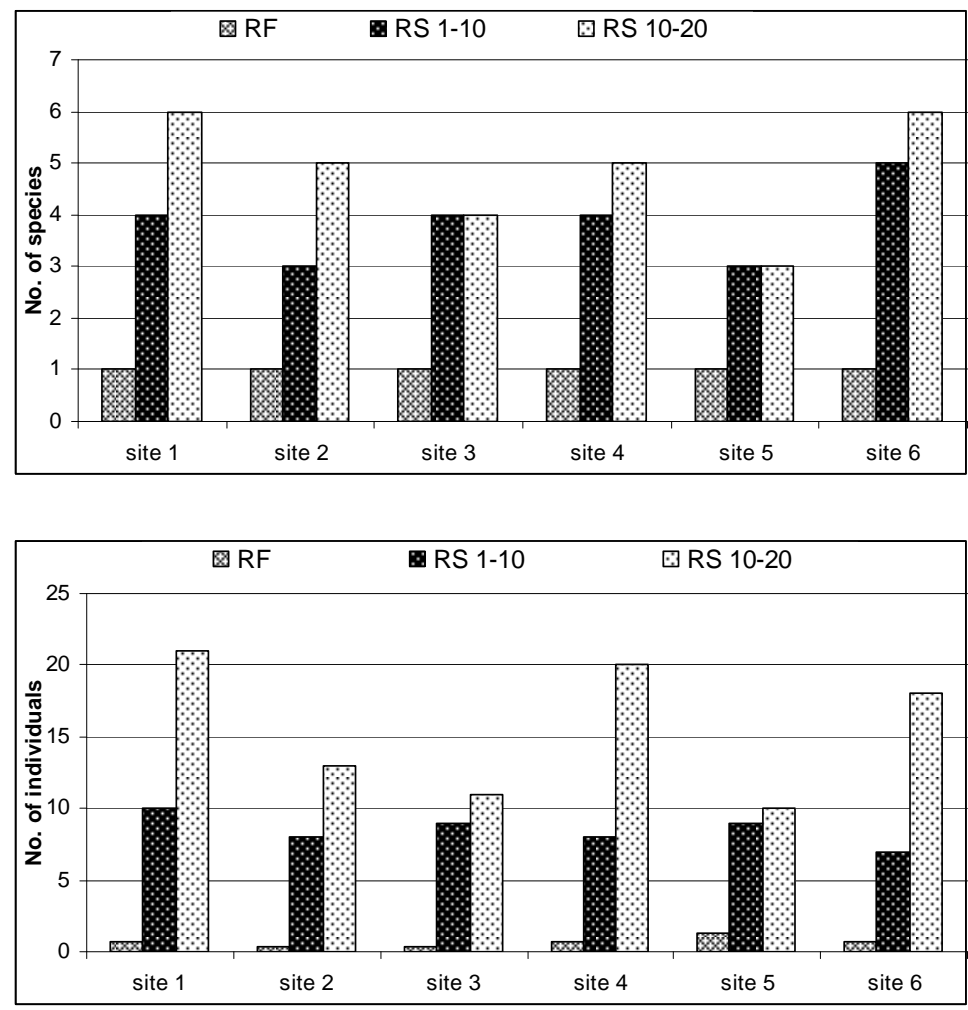

Figure (2). Average number of species and individuals for angelfishes at the reef flat (RF) and reef slope (1-10 m \& 10-20 m) at six different sites in Shalateen region. 


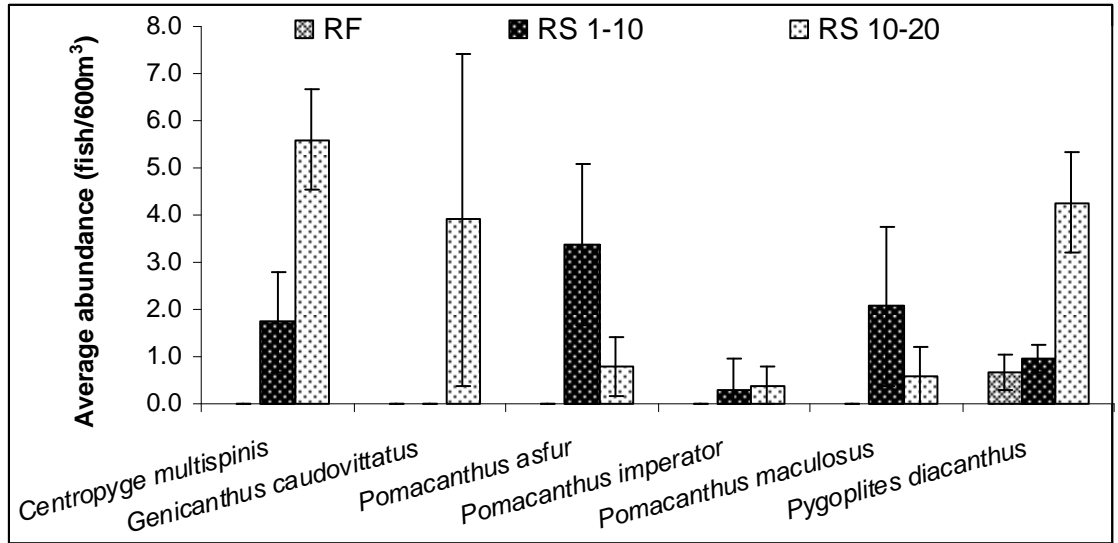

Figure (3). Average abundance of angelfish species at the reef flat (RF) and slope (RS 1$10 \& 10-20 \mathrm{~m}$ ) in Shalateen region.

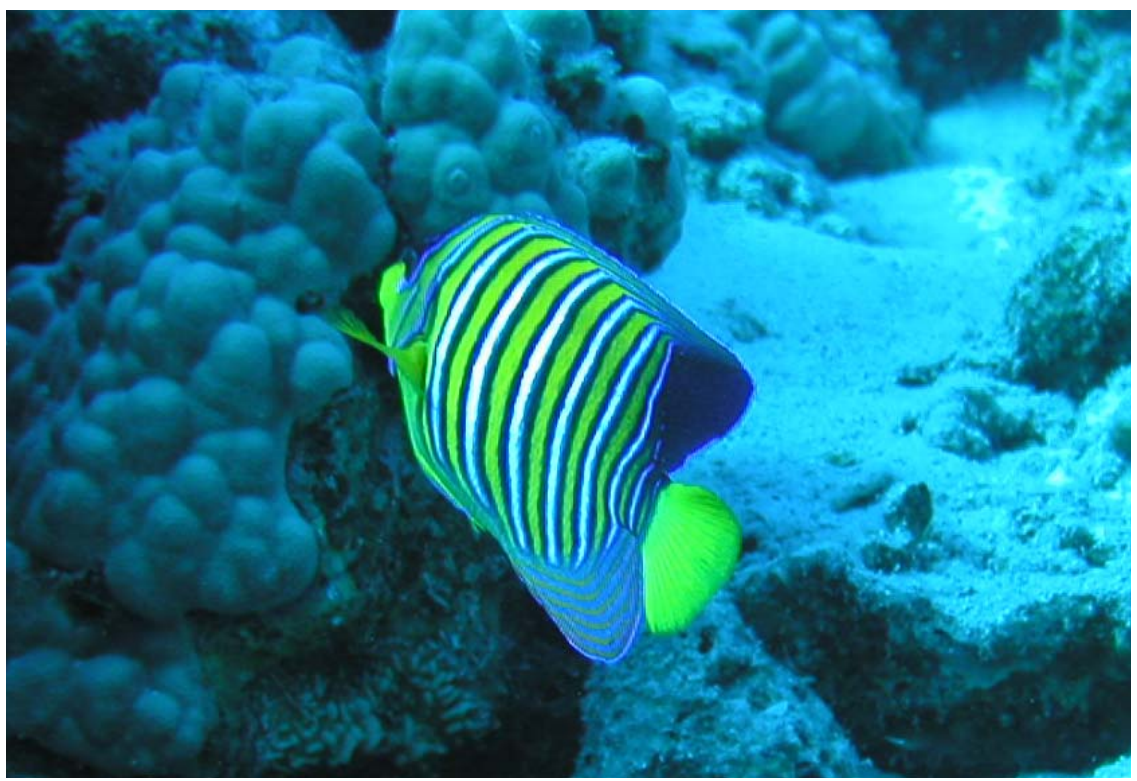

Figure 4. The royal angelfish, Pygoplites diacanthus, was recorded in all sites and all reef zones at Shalateen region.

\section{Feeding activities}

Table (3) shows the average feeding rate, mode, guild, time and prey items for each species of the angelfishes on the reefs in Shalatenn region. The highest feeding rate was recorded for Centropyge multispinis, with 84.3 \pm 26.4 bites $\cdot(5 \mathrm{~min})^{-1}$, while the lowest value was recorded for Pomacanthus maculosus, 
with $58.9 \pm 21.6$ bites $\cdot(5 \mathrm{~min})^{-1}$. The feeding rates of all angelfish species did not differ significantly between different sites (One-way ANOVA). Based on data pooled for the entire study, most species are selective feeders in the sense that they prefer algae and sponges than other food items. Most species of angelfishes use biting mode for feeding and described as diurnal feeders, except Genicanthus caudovittatus which use ram mode for feeding on zooplanktons and described as nocturnal feeder. Invertebrate-feeders (IV) were represented by three species of angelfishes, namely: Pomacanthus asfur, $P$. imperator and $P$. maculosus (Table 3). Omnivores (OM) were represented by two species: Centropyge multispinis and Pygoplites diacanthus, which feed on algae, cnidarians and sponges. The last species, Genicanthus caudovittatus, feeds on zooplanktons (mainly copopods) in depth of more than $15 \mathrm{~m}$.

Table (3). The feeding activities of angelfishes species in Shalatenn region in the northern Red Sea. (feeding mode; B: biting, R: ram), (feeding guild; IV: invertebrate-feeder, OM: omnivore, PL: planktivore), (feeding time; D: diurnal, $\mathrm{N}$ : nocturnal). All feeding activities were based on visual field observations.

\begin{tabular}{|c|c|c|c|c|c|}
\hline $\begin{array}{l}\text { angelfish } \\
\text { species }\end{array}$ & $\begin{array}{l}\text { feeding } \\
\text { rate }\end{array}$ & $\begin{array}{c}\text { feeding } \\
\text { mode }\end{array}$ & $\begin{array}{l}\text { feeding } \\
\text { guild }\end{array}$ & $\begin{array}{c}\text { feeding } \\
\text { time }\end{array}$ & $\begin{array}{l}\text { prey } \\
\text { items }\end{array}$ \\
\hline Centropyge multispinis & $84.3 \pm 26.4$ & B & $\mathrm{OM}$ & $\mathrm{D}$ & $\begin{array}{l}\text { algae, cnidarians, } \\
\text { sponges }\end{array}$ \\
\hline Genicanthus caudovittatus & - & $\mathrm{R}$ & PL & $\mathrm{N}$ & $\begin{array}{l}\text { Zooplanktons, } \\
\text { mainly copopoda }\end{array}$ \\
\hline Pomacanthus asfur & $74.1 \pm 14.1$ & B & IV & $\mathrm{D}$ & sponges, tunicates \\
\hline Pomacanthus imperator & $69.2 \pm 18.3$ & B & IV & D & sponges, tunicates \\
\hline Pomacanthus maculosus & $58.9 \pm 21.6$ & B & IV & $\mathrm{D}$ & sponges, tunicates \\
\hline Pygoplites diacanthus & $65.4 \pm 13.5$ & B & $\mathrm{OM}$ & $\mathrm{D}$ & $\begin{array}{l}\text { algae, cnidarians, } \\
\text { sponges }\end{array}$ \\
\hline
\end{tabular}

\section{DISCUSSION}

Marine angelfishes of the family Pomacanthidae are typical coral reef inhabitants and are economically important as high priced ornamental fishes (Steene, 1977; Allen, 1979; Moenich, 1991). Angelfishes have been considered as one of the most famous and beautiful fishes among the coral reef fish community. The family Pomacanthidae has circumtropical distribution with 88 species in eight genera (Fraser-Brunner, 1933; Chung and Woo, 1998; Debelius et al., 2003). In the Red Sea, angelfishes were represented by 9 species (Goren and Dor, 1994). During the present study, six species of angelfishes were recognized in Shalateen region from reef flat $(0.5-1 \mathrm{~m})$ to reef slope until $20 \mathrm{~m}$ depth. Angelfish community in the study area was represented by $66.7 \%$ of the total number of angelfish species in Red Sea, and $6.8 \%$ of the total number of angelfish species all over the world. Alwany (1997) and Khalaf \& Disi (1997) reported 5 species of angelfishes in the Gulf of Aqaba. This gives evidence that the angelfish community is relatively the same inside the fringing reefs of Egyptian coast of the Red Sea. 


\section{Distribution}

The present study shows that, there are six species of angelfishes which occur at depth range between reef flat $(0.5-1 \mathrm{~m})$ and $20 \mathrm{~m}$ in different locations in Shalateen region in the northern Red Sea. The comparative data were not available in the literature. So it is safe to say that, this is the first attempt to study the distribution of angelfishes in this area (reefs in Shalateen region) of Red Sea. In spite the healthy coral communities of the northern Red Sea, a low diversity of species of angelfishes was observed. In contrast, the number of individuals (abundance) was higher than other areas, such as the French Polynesia and the Great Barrier Reef. The closed-system of the Red Sea may be the important factor, which leads to scarcity of fish species. So, the number of individuals is high because of the healthy coral communities of the northern Red Sea.

The abundance and distribution of fishes is dependent on several distinct factors such as recruitment, habitat structure, food availability, and environmental factors (Jones, 1991; Williams, 1991). Most of the investigations about the factors explaining the abundance of fishes have studied some fishes, and little attention has been paid to angelfish populations. Many coral reef fishes tend to increase in both abundance and number of species with increasing depth on fringing reefs (Roberts and Ormond, 1987). In the present study (Shalateen region), the abundance and number of species of the angelfishes were increased with increasing depth according to Roberts and Ormond (1987) and Alwany et al. (2007).

Olivotto et al. (2006) indicated that the high water temperature is better for larval survival of several coral reef fish groups and the angelfishes are not exception for this base. The temperature in Shalateen region may reach a peak in summer. So the temperature may play essential role in the angelfish horizontal distributions in the Gulf. On the other hand, the vertical distribution of angelfishes shows increasing in deeper depths, where the highest average abundance of angelfishes was recorded on the $20 \mathrm{~m}\left(93.0 \pm 6.1 \mathrm{fish} / 600 \mathrm{~m}^{3}\right)$. Angelfish species are greatly affected with depth, except the royal angelfish, Pygoplites diacanthus, which was represented in all sites and all reef zones in Shalateen region (Figs. 3 and 4). In the present study, food availability may play an essential role in the vertical distributions of angelfishes in Shalateen region.

\section{Feeding activities}

In general, feeding mode in pomacanthids varied from biting, suction to ram mode. In fact, intramandibular articulation may be the most significant morphological specialization in the feeding apparatus of pomacanthids (Konow and Bellwood, 2005). In addition, the mandible protrusion of $30 \%$ of head length of most genera of angelfishes (Konow and Bellwood, 2005), may be considered as extreme and rare in teleosts. This is also considered as another adaptation in pomacanthids for their food items (especially sponges). In the present study, most species of angelfishes use biting mode for feeding and 
described as diurnal feeders, except Genicanthus caudovittatus which use ram mode for feeding on zooplanktons and nocturnal feeder (Table 3).

The feeding habits of the reef fishes affects the distribution of those fishes. Herbivores and omnivores are much more abundant in the shallow reef flat region than on the outer slope of the reef (Bouchon-Navaro and HarmelinVivien, 1981). This is likely to be related to the abundance of algae and different food items on the shallow region of the reef. In contrast, carnivorous or invertebrate-feeder fishes are usually more abundant on the outer reef slope. The two omnivore species, Centropyge multispinis and Pygoplites diacanthus which feed on algae, cnidarians and sponges, are distributed in wide range of habitats. On the other hand, Genicanthus caudovittatus which feeds on zooplankton preferred deeper habitats of more than $15 \mathrm{~m}$ depth.

\section{REFERENCES}

Allen, G.R. (1979). Butterfly and angelfishes of the world, vol. 2, John Wiley and Sons, New York, 352 pp.

Allen, G.R.; Steene, R. and Allen, M. (1998). A Guide to angelfishes and butterflyfishes. Odyssey Publishing, Perth.

Alwany, M.A. (1997). Ecological and biological studies on some coral reef fishes in south Sinai (Red Sea-Gulf of Aqaba). M. Sc. Thesis, Suez Canal University, Ismailia., Egypt, 283 pp.

Alwany, M.A.; El-Etreby, S.G. and Hanafy, M.H. (2007). Distribution and abundance of buterflyfishes along the Gulf of Aqaba, Egypt. J. Fish. Aquat. Sci., 2(6): 395-402.

Bellwood, D.R.; Herwerden, L. and Konow N. (2004). Evolution and biogeography of marine angelfishes (Pisces: Pomacanthidae). Molec. Phylog. Evolu., 33: 140-155.

Bouchon-Navaro, Y. and Harmelin-Vivien M.L. (1981). Quantitative distribution of herbivorous fishes in the Gulf of Aqaba (Red Sea). Mar. Biol., 63: 79-86.

Brock, V.E. (1954). A preliminary report on a method of estimating reef fish populations. J. Wildl. Manage., 18: 297-308.

Chung, K.C. and Woo, N.Y.S. (1998). Phylogenetic relationships of the pomacanthidae (Pisces: Teleostei) inferred from from allozyme variation. J. Zool. Lond., 246: 215-231. 
Delbelius, H.; Tanaka, H. and Kuiter, R.H. (2003). Angelfishes, a Comprehensive Guide to Pomacanthidae. TMC Publishing, Chorley, UK.

Fraser-Brunner, A. (1933). A revision of Chaetodon fishes of subfamily Pomachantidae. Proc. Zool. Soc. Lond., pp. 543-599.

Goren, M. and Dor, M. (1994). An updated checklist of the fishes of the Red Sea. Clofres II. The Israel Academy of Sciences and Humanities, Eilat, $120 \mathrm{pp}$.

Harmelin-Vivien, M.L. (1989). Implications of feeding specialization on the recruitment processes and community structure of butterflyfishes. Env. Biol. Fish., 25: 101-110.

Harmelin-Vivien, M.L.; Harmelin, J.G.; Chauvet, C.; Duval, C.; Galzin, R.; Lejeune, P.; Barnabé, G.; Blanc, F.; Ghevalier, R.; Duclerc J. and Lasserre, G. (1985). Evaluation visuelle des peuplements et populations de poisons: methods et problemes. Review of Ecology, 40: 468-539.

Khalaf, M.A. and Disi, A.M. (1997). Fishes of the Gulf of Aqaba. Marine Science Station, Aqaba, Jordan, 252 pp.

Khalaf, M.A. and Kochzius, M. (2002a). Community structure and biogeography of shore fishes in the Gulf of Aqaba, Red Sea. Helgol. Mar. Res., 55: 252-284.

Khalaf, M.A. and Kochzius, M. (2002b). Changes in trophic community structure of shore fishes at an industrial site in the Gulf of Aqaba, Red Sea. Mar. Ecol. Prog. Ser., 239: 287-299.

Konow, N. and Bellwood, D.R. (2005). Prey-capture in Pomacanthus semicirculatus (Teleostei, Pomacanthidae): functional implications of intramandibular joints in marine angelfishes. J. Exp. Biol., 208: 1421-1433.

Jones, G.P. (1991). Postrecruitment processes in the ecology of coral reef fishes populations: a multifactorial perspective. In: P.F. Sale (ed.) The ecology of coral reef fishes. New York, Academic Press, San Diego, pp.294-328

Moenich, D.R. (1991). Marine angels-Pomacanthus. T.F.H. Mag. 39: 68-81. 
Olivotto, I.; Holt, S.A.; Carnevali, O. and Holt G.J. (2006). Spawning, early development, and first feeding in the lemonpeel angelfish Centropyge flavissimus. Aquacult., 253: 270-278.

Pielou, E.C. (1969). An introduction to mathematical ecology. Wiley Interscience, New York, 286 pp.

Pyle, R.L. (2003). A systematic treatment of the reef-fish family Pomacanthidae (Pisces: Perciformes). Ph.D. Dissertation, University of Hawaii, Honolulu, 422 pp.

Randall, J.E. (1983). Red Sea reef fishes. IMMEL Publishing, London, 192 pp.

Reese, E.S. (1975). A comparative field study of the social behaviour and related ecology of reef fishes of the family Chaetodontidae. Zeitschrift für Tierpsychologie, 37: 37-61.

Reese, E.S. (1977). Coevolution of corals and coral feeding fishes of the family Chaetodontidae. Proceeding of 3rd International Coral Reef Symposium 1: 267-274.

Roberts, C.M. and Ormond, R.F. (1987). Habitat complexity and coral reef fish diversity and abundance on Red Sea fringing reefs. Mar. Ecol. Prog. Ser., $41 ; 1-8$.

Samoils, M.A. and Carlos G.M. (2000). Determining methods of underwater visual census for estimating the abundance of coral reef fishes. Env. Biol. Fish., 57: 289-304.

Steene, R.C. (1977). Butterfly and angelfishes of the world. Vol. 1. Australia, Reed, Sydney.

Thresher, R.E. (1982). Courtship and spawning in the emperor angelfish Pomacanthus imperator, with comments on reproduction by other pomacanthid fishes. Mar. Biol., 70 (2): 149-156. 